\title{
Understanding atmospheric peroxyformic acid chemistry: observation, modeling and implication
}

\section{H. Liang, Z. M. Chen, D. Huang, Q. Q. Wu, and L. B. Huang}

State Key Laboratory of Environmental Simulation and Pollution Control, College of

Environmental Sciences and Engineering, Peking University, Beijing 100871, China

Received: 1 December 2014 - Accepted: 24 December 2014 - Published: 22 January 2015

Correspondence to: Z. M. Chen (zmchen @pku.edu.cn)

Published by Copernicus Publications on behalf of the European Geosciences Union.

\section{Understanding atmospheric \\ peroxyformic acid chemistry}

\section{H. Liang et al.}

\section{Title Page}




\section{Abstract}

The existence and importance of peroxyformic acid (PFA) in the atmosphere has been under controversy. We present here, for the first time, the observation data for PFA from four field measurements carried out in China. These data provided powerful evidence 5 that PFA can stay in the atmosphere, typically in dozens of pptv level. The relationship between PFA and other detected peroxides was examined. The results showed that PFA had a strong positive correlation with its homolog, peroxyacetic acid, due to their similar sources and sinks. Through an evaluation of PFA production and removal rates, we proposed that the reactions between peroxyformyl radical $\left(\mathrm{HC}(\mathrm{O}) \mathrm{O}_{2}\right)$ and formaldehyde or the hydroperoxyl radical $\left(\mathrm{HO}_{2}\right)$ were likely to be the major source and degradation into formic acid (FA) was likely to be the major sink for PFA. Based on a box model evaluation, we proposed that the $\mathrm{HC}(\mathrm{O}) \mathrm{O}_{2}$ and PFA chemistry was a major source for $\mathrm{FA}$ under low $\mathrm{NO}_{\mathrm{x}}$ conditions. Furthermore, it is found that the impact of the $\mathrm{HC}(\mathrm{O}) \mathrm{O}_{2}$ and PFA chemistry on radical cycling was dependent on the yield of $\mathrm{HC}(\mathrm{O}) \mathrm{O}_{2}$ 15 radical from $\mathrm{HC}(\mathrm{O})+\mathrm{O}_{2}$ reaction. When this yield exceeded $50 \%$, the $\mathrm{HC}(\mathrm{O}) \mathrm{O}_{2}$ and PFA chemistry should not be neglected for calculating the radical budget. To make clear the exact importance of $\mathrm{HC}(\mathrm{O}) \mathrm{O}_{2}$ and PFA chemistry in the atmosphere, further kinetic, field and modeling studies are required.

\section{Introduction}

(O) play vital roles in both gas and condensed phases in the atmosphere. First, they enhance the acidity of the atmospheric aqueous phase, both in their own right and by oxidizing dissolved tetravalent sulfur (S(IV)) into sulfuric acid or sulfate (Stein and Saylor, 2012). Second, they serve as the terminal products of the peroxy radicals and thereby ending the radical cycling (e.g., Niki et al., 1985). Third, the formation of OPAs are competing with the formation of peroxyacyl nitrates (PANs, $\left.\mathrm{RC}(\mathrm{O}) \mathrm{OONO}_{2}\right)$, which are the critical pollutants and indica-
ACPD

15, 2055-2084, 2015

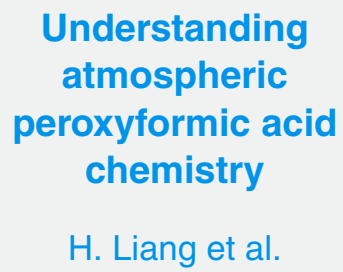

Understanding

atmospheric

peroxyformic acid

chemistry

H. Liang et al.

Title Page

Abstract

Introduction

Conclusions

References

Tables

Figures

14

$\rightarrow 1$

Back

$>$

Close

Full Screen / Esc

Printer-friendly Version

Interactive Discussion 
tors of the photochemical smog (Phillips et al., 2013). In addition, some high molecular weight OPAs partition into the particle phase due to their low volatility (Kroll and Seinfeld, 2008). These OPAs can subsequently react with carbonyls in the particle phase to form carboxylic acids or acyl peroxyhemiacetals, which have even lower volatility than 5 OPAs (Ziemann and Atkinson, 2012). These low-volatility compounds can contribute to the components of secondary organic aerosols (SOAs).

Using different measurement techniques, a number of OPAs, such as peroxyacetic acid (PAA), peroxypropionic acid (PPA) and methylacrylic peroxyacid (MPA), were detected in the atmosphere in previous studies (He et al., 2010; Zhang et al., 2012; 10 Phillips et al., 2013). However, the peroxyformic acid (PFA, $\mathrm{HC}(\mathrm{O}) \mathrm{OOH}$ ), the OPA with the simplest molecular structure, has never been directly detected in the atmosphere to our knowledge. Unfortunately, the difficult generation and easy decomposition of PFA makes it impossible to determine the existence of PFA theoretically. On one hand, PFA has a reactive precursor. The generation of OPAs is known to predominantly result 15 from the reactions between peroxyacyl radicals $\left(\mathrm{RC}(\mathrm{O}) \mathrm{O}_{2}\right)$ and hydroperoxyl radicals $\left(\mathrm{HO}_{2}\right)$. The corresponding precursor of PFA in this reaction, i.e., the peroxyformyl radical $\left(\mathrm{HC}(\mathrm{O}) \mathrm{O}_{2}\right)$, was thought either not generated or rapidly decomposed to yield $\mathrm{CO}$ and $\mathrm{HO}_{2}$ (Langford and Moore, 1984), as shown in Reaction (R1). On the other hand, PFA itself can rapidly decompose, in both gas and aqueous phases. Gaseous PFA can spontaneously decompose into formic acid (FA, $\mathrm{HC}(\mathrm{O}) \mathrm{OH}$ ) through Reaction (R2), even at low temperature (Maker et al., 1977). When PFA enters the aqueous phase, it can readily isomerize to carbonic acid and decompose into $\mathrm{CO}_{2}$ and $\mathrm{H}_{2} \mathrm{O}$ through Reaction (R3).

$\mathrm{HC}(\mathrm{O}) \mathrm{O}_{2} \rightarrow \mathrm{CO}+\mathrm{HO}_{2}$

$2 \mathrm{HC}(\mathrm{O}) \mathrm{OOH} \rightarrow 2 \mathrm{HC}(\mathrm{O}) \mathrm{OH}+\mathrm{O}_{2}$

$\mathrm{HC}(\mathrm{O}) \mathrm{OOH}(\mathrm{aq}) \rightarrow \mathrm{H}_{2} \mathrm{CO}_{3}(\mathrm{aq}) \rightarrow \mathrm{CO}_{2}+\mathrm{H}_{2} \mathrm{O}$

As a consequence of the non-detection, difficult generation and rapid decomposition of PFA in the atmosphere, PFA-related chemistry has been ignored by most of 2057
ACPD

15, 2055-2084, 2015

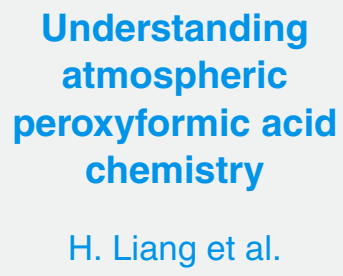

Understanding

atmospheric

peroxyformic acid

chemistry

H. Liang et al.

Title Page

Abstract

Introduction

Conclusions

References

Tables

Figures

14

$\Delta \mathbf{I}$

4

Back

Close

Full Screen / Esc

Printer-friendly Version

Interactive Discussion 
the current chemical mechanisms. However, the conclusion that PFA does not exist in the atmosphere is in fact imprudent. Actually, the ignorance of PFA-related chemistry may bring potentially important impact on the predictions of radicals and other trace gases. Therefore, the purpose of the current paper is to demonstrate the existence 5 of atmospheric PFA on the basis of a number of specific observations, to report the concentrations and variations of atmospheric PFA, to give a preliminary description to its atmospheric budget and behaviors, and to discuss the possible implications of PFA and $\mathrm{HC}(\mathrm{O}) \mathrm{O}_{2}$ related chemistry on atmospheric chemistry.

\section{Methodology}

\subsection{Site description}

Measurements for atmospheric peroxides were conducted separately at two locations, namely, Peking University (PKU) Site and Gucheng (GC) Site.

The PKU site $\left(39.99^{\circ} \mathrm{N}, 116.30^{\circ} \mathrm{E}\right)$ is a typical urban observation site located in the campus of Peking University, northwest downtown of the Beijing city. A series of peroxide measurements have been performed in this site since 2006 ( $\mathrm{He}$ et al., 2010; Zhang et al., 2010, 2012; Liang et al., 2013). The campus of PKU is surrounded by two traffic thoroughfares where vehicles keep flowing continuously. The instrumentations were mounted on the top of a six-story building, with the sampling inlet $\sim 26 \mathrm{~m}$ above the ground. Three peroxide measurements, namely BJ-2012S (11 August-4 September 2012), BJ-2012F (18-28 September) and BJ-2013 (8-27 June 2013), were carried out in this site.

The GC Site $\left(39.16^{\circ} \mathrm{N}, 115.74^{\circ} \mathrm{E}\right)$ is a rural site located in the central meteorological bureau (CMB) farm in the North China Plain, $100 \mathrm{~km}$ southwest of the Beijing city. The instrumentations were mounted in a container, which was surrounded by vast wheat fields. The sampling inlet was $\sim 5 \mathrm{~m}$ above the ground. One peroxide measurement, i.e. GC-2013 (10-27 June 2013), was carried out in this site.
ACPD

$15,2055-2084,2015$

Understanding

atmospheric

peroxyformic acid

chemistry

H. Liang et al.

Title Page

Abstract

Introduction

Conclusions

References

Tables

Figures

14

$>1$

Back

$>$

Close

Full Screen / Esc

Printer-friendly Version

Interactive Discussion 


\subsection{Sampling and analyzing method}

The sampler used to collect the peroxide components in the ambient air is a scrubbing coil at $\sim 4^{\circ} \mathrm{C}$, which is a glass made coil with an effective length of $\sim 100 \mathrm{~cm}$ and an inside diameter of $2 \mathrm{~mm}$. The ambient air is pumped into this sampler with a flow rate 5 of $2.7 \mathrm{sIm}$ (standard liter per minute), to ensure the air resides no more than $2 \mathrm{~s}$ in the sampler. In the sampler, the air is mixed with the eluent, $5 \times 10^{-3} \mathrm{MH}_{3} \mathrm{PO}_{4}$ in water, which is delivered into the coil by a peristaltic pump at $0.2 \mathrm{~mL} \mathrm{~min}^{-1}$. Then the eluent, mixed with the sampled peroxide component, is delivered into the high performance liquid chromatography (HPLC) system for detection. The residence time in the coil for io the eluent is estimated to be $\sim 1 \mathrm{~min}$.

The analyzing method for peroxides is the HPLC post column derivatization method, which means that peroxides are derived into fluorescent matters for detection after separated in the HPLC column. Once collected, samples are injected into the HPLC system, carried by the mobile phase, separated in the column and derived for fluorescence detection. The mobile phase for the HPLC system is $5 \times 10^{-3} \mathrm{MH}_{3} \mathrm{PO}_{4}$ with a flow rate of $0.5 \mathrm{~mL} \mathrm{~min}^{-1}$. The derivatization reagent is a mixture of Hemin and PHPAA (parahydroxyphenylacetic acid). PHPAA reacts with peroxides to form the fluorescent matter and Hemin serves as the catalyst for the reaction. The derivatization reaction takes place in the $\sim 3 \mathrm{~m}$ Teflon tube at a temperature of $\sim 40^{\circ} \mathrm{C}$. More details about the sampling and analyzing method for peroxides can be found in Hua et al. (2008).

The peroxide components are separated by an HPLC column, in which the retention time for PFA chromatographic peak is 8.6 min (Huang et al., 2013), between the peaks of hydroxymethyl hydroperoxide (HMHP, $7.1 \mathrm{~min}$ ) and Bis-hydroxymethyl peroxide (BHMP, $8.8 \mathrm{~min}$ ). The relative position of PFA peak coincides with that reported in Kok et al. (1995).

PFA is unlikely to be significantly produced in the analytical system. On one hand, the $\mathrm{C} 1$ precursor for PFA, $\mathrm{HCHO}$ (formaldehyde), was not added in the eluent. On the
ACPD

$15,2055-2084,2015$

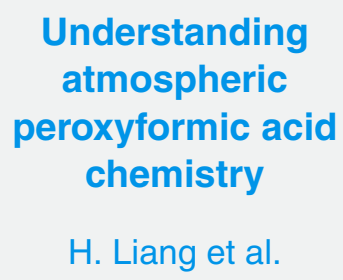

Understanding

atmospheric

peroxyformic acid

chemistry

H. Liang et al.

Title Page

Abstract

Introduction

Conclusions

References

Tables

Figures

14

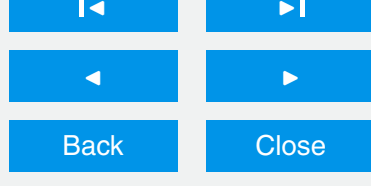

Full Screen / Esc

Printer-friendly Version

Interactive Discussion 
other hand, $\mathrm{H}_{2} \mathrm{O}_{2}+\mathrm{HCHO}$ reaction is not able to significantly produce PFA in solution, which is demonstrated by our condition experiments.

ACPD

15, 2055-2084, 2015

\subsection{Measurement method for other trace gases}

Besides peroxides, other trace gases including $\mathrm{SO}_{2}, \mathrm{CO}, \mathrm{NO}, \mathrm{NO}_{2}$ and $\mathrm{O}_{3}$, were mon5 itored simultaneously during each measurement, using a set of corresponding online analyzers (Thermo 42i, 43i, 48i, and 49i analyzers for $\mathrm{NO}-\mathrm{NO}_{2}-\mathrm{NO}_{\mathrm{x}}, \mathrm{SO}_{2}, \mathrm{CO}$ and $\mathrm{O}_{3}$, respectively). In addition, mass concentrations of $\mathrm{PM}_{2.5}$ were determined by a TEOM 1400a analyzer. The time resolution for the trace gases and $\mathrm{PM}_{2.5}$ were $1 \mathrm{~min}$. At PKU site, meteorological parameters (i.e., ambient temperature, relative humidity, wind direction and wind speed) were recorded continuously by a weather station (Met One Instruments Inc., USA). At GC site, meteorological parameters were not recorded. Instead, we use the $1 \mathrm{~h}$ average data provided by local weather station.

\subsection{Modeling method}

A modeling approach was performed with a box model based on Version 6 of the 15 Carbon Bond (CB6) Mechanism (Yarwood et al., 2010). The original CB6 Mechanism contains 77 gas phase species and 218 gas phase reactions (including photolysis reactions). In this study, the mechanism is extended by PFA and $\mathrm{HC}(\mathrm{O}) \mathrm{O}_{2}$ radical related chemistry ( 2 new species and 21 reactions). The reaction equations are given in detail in Table $\mathrm{S} 1$ in the Supplement. The rates of these reactions were assumed to be the same with the corresponding reactions of PAA and peroxyacetyl radical. The initial concentrations of long lived species were set as follows: 1 ppmv $\mathrm{CO}, 2 \mathrm{ppmv} \mathrm{CH}_{4}, 30 \mathrm{ppbvO}_{3}$ and $5 \mathrm{ppbv} \mathrm{HCHO}$. Then the model received emissions of $\mathrm{NO}$ and lumped volatile organic compounds (VOCs) and these emissions were maintained throughout the whole model runs. The emission rates of VOCs were calculated based on the VOC emission ratio vs. CO in Beijing reported by Yuan et al. (2012) and a CO emission rate of $2 \times 10^{13}$ molecules $\mathrm{cm}^{-2} \mathrm{~s}^{-1}$. The calculated VOC emission

\section{Understanding \\ atmospheric \\ peroxyformic acid \\ chemistry \\ H. Liang et al.}

Title Page

Abstract

Introduction

Conclusions

References

Tables

Figures

14

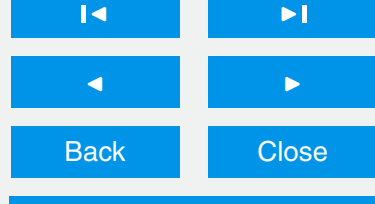

Full Screen / Esc

Printer-friendly Version

Interactive Discussion 
rates are listed in Table S2 in the Supplement. $\mathrm{NO}$ emission rate was fixed constant throughout a single run and varied over the range from $6.0 \times 10^{9}$ molecules cm $\mathrm{cm}^{-2} \mathrm{~s}^{-1}$ to $1.2 \times 10^{12}$ molecules $\mathrm{cm}^{-2} \mathrm{~s}^{-1}$ in different model cases. The photolysis frequencies of trace gases were calculated with a Tropospheric Ultraviolet and Visible (TUV, version 5 5.0; Madronich, 2002) radiation model. In this study, the box model is applied to examine the influence of PFA and $\mathrm{HC}(\mathrm{O}) \mathrm{O}_{2}$ radical chemistry on the production of formic acid and the budget of $\mathrm{RO}_{\mathrm{x}}$ radicals. The physical losses of trace gases (i.e., deposition and phase transfer) and the changes of the planet boundary layer height were not included in the model runs, thereby enabling the results directly reflecting the upper 10 limit of the potential impact of the mechanistic changes.

\section{Observations}

\subsection{PFA levels}

Gas phase PFA concentration data were collected from four field measurements, i.e., BJ-2012S, BJ-2012F, BJ-2013 and GC-2013, as is shown in Fig. 1. PAA concentra15 tion data were also presented in Fig. 1 as reference. The detection limit for PFA and PAA was estimated to be $10 \mathrm{pptv}$ (parts per trillion by volume). It should be noted that data under detection limit (D.L.) were not replaced in Fig. 1 in order to better reveal the variation trend, whereas these data were replaced with D.L. $/ \sqrt{2}$ (i.e., 7.1 pptv) for statistical calculation. The mean $( \pm S D)$ concentrations of PFA were $21 \pm 19$ pptv for BJ-2012S, $10 \pm 7$ pptv for BJ-2012F, $31 \pm 37$ pptv for BJ-2013 and $12 \pm 13$ pptv for GC2013. It can be seen that PFA concentration showed an evident seasonal and spatial variation. On one hand, PFA showed much higher level in summer (BJ-2012S) than in fall (BJ-2012F) in the year 2012, indicating that PFA is a photochemical product subject to the solar radiation intensity. On the other hand, PFA observed at PKU site was much higher than that observed at GC site at the same time, suggesting that PFA was more readily formed and stayed in polluted area. The typical concentration of PFA in the at-

\section{ACPD}

15, 2055-2084, 2015

Understanding

atmospheric

peroxyformic acid

chemistry

H. Liang et al.

Title Page

Abstract

Introduction

Conclusions

References

Tables

Figures

14

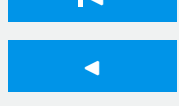

Back

$\Delta$

$\triangleright$

Close

Full Screen / Esc

Printer-friendly Version

Interactive Discussion 
mosphere, as is seen, was within the range from several pptv to dozens of pptv, which contributed only a minor part to the total detected peroxides. However, its total production can be comparable with other peroxides if the rapid degradation of PFA was taken into consideration. It was also found that PFA and PAA were the most often detected 5 peroxides over PKU and GC sites. They were detected even at the time when $\mathrm{H}_{2} \mathrm{O}_{2}$ and methyl hydroperoxide (MHP) were not detected. Like other peroxides, PFA had an obvious daily cycle, with a rapid growth commencing from $\sim 10: 00 \mathrm{LT}$ and a peak concentration in the late afternoon. High concentrations sometimes occurred at night, implying gas phase photochemistry was not the exclusive source of PFA.

10 The Henry's law constant of PFA has never been determined in previous studies. Due to the instability of PFA, its Henry's law constant was not able to be determined using the previous estimation methods, e.g., HWINb (Meylan and Howard, 2000), SPARC (Hilal et al., 2008) and GROMHE (Raventos-Duran et al., 2010). Here, we provide an estimation of the Henry's law constant of PFA on the basis of the PFA observation data 15 in both gas phase and rainwater. PFA was determined in the rainwater on 22 June 2013 during GC-2013 measurement. On that day, the rain kept falling from the morning to $\sim$ 15:00 LT in the afternoon. Air and rain samples were collected and determined alternately. Figure 2 shows the temporal profile of PFA and PAA in the gas phase and rainwater. It can be seen that PFA and PAA had a similar time variation in both gas and 20 aqueous phase, indicating their sources and sinks were similar. OPAs in the rainwater generally come from two sources: mass transfer from the gas phase and aqueous phase production. In our previous study (Liang et al., 2013), we have concluded that the partitioning of PAA deviated apparently from the Henry's law equilibrium due to the aqueous phase reaction. Given the similar temporal profile with PAA in both phases, 25 it can be inferred that the gas-aqueous phase partitioning of PFA also deviates from the Henry's law equilibrium. Considering the similar behaviors of PFA and PAA, here we use an indirect method to estimate the Henry's law constant of PFA, that is, to make a comparison with PAA in both gas and aqueous phase. As is seen in Fig. 2, the average ratio of PAA to PFA concentration in the gas phase is $\sim 5$ while the value

\section{ACPD}

15, 2055-2084, 2015

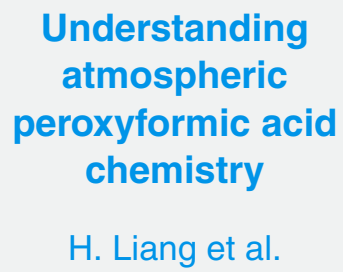

Understanding atmospheric

peroxyformic acid chemistry

H. Liang et al.

Title Page

Abstract Introduction

Conclusions

References

Tables

Figures

14

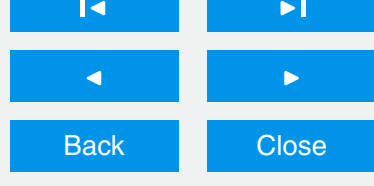

Full Screen / Esc

Printer-friendly Version

Interactive Discussion 
turns into $\sim 20$ in rainwater. Therefore, the Henry's law constant of PFA is estimated to be a quarter of the value of PAA, i.e. $\sim 210 \mathrm{Matm}^{-1}$ at $298 \mathrm{~K}$. Such low Henry's law constant implies that PFA will majorly partition into the gas phase if it is generated in the aqueous phase. Therefore, aqueous production may serve as a potential source 5 for gas phase PFA. The correlations between PFA and PAA in the gas phase will be further discussed in Sect. 3.2.1.

\subsection{Correlations with other peroxides}

\subsubsection{PFA vs. PAA}

Phillips et al. (2013) has reported a strong positive correlation between PAA and three 10 higher molecule weight OPAs. Likewise, we present here a strong positive correlation between PFA and PAA, as illustrated in Fig. 3 . The strong correlations between different OPAs indicate that they behave similarly in the atmosphere: they are produced through the oxidation of hydrocarbons and removed through $\mathrm{OH}$-initiated reactions, photolysis and dry deposition. PFA and its precursor, the $\mathrm{HC}(\mathrm{O}) \mathrm{O}_{2}$ radical, are instable in the gas phase, as mentioned in Sect. 1. Therefore, PFA concentration is typically lower than PAA. In fact, the ratio of PFA to PAA (PFA/PAA) in the gas phase keeps changing, within a range from 0.05 to 1 . Several factors can affect the PFA/PAA ratio. The most important factor seems to be the solar radiation. As is shown in Fig. 1, observed PFA/PAA in June (BJ-2012S) was about 0.10 on average whereas the ratio in August and September (BJ-2012F) was about 0.33 on average. This can be either owing to an easier photochemical production of PAA or an easier photochemical removal of PFA. The same conclusion can as well be drawn from the daily cycle of PFA/PAA: peaking at 07:00 LT in the early morning and going down continuously in the daytime. The peak value of PFA/PAA at $\sim 07: 00 \mathrm{LT}$, reaching $\sim 0.70$, is significantly higher than the value at other time. This is because both PFA and PAA tend to be under detection limit after strong removal overnight. As PFA and PAA share a same detection limit, their ratio will be unity when they are both under detection limit. Another possible factor affecting
ACPD

$15,2055-2084,2015$

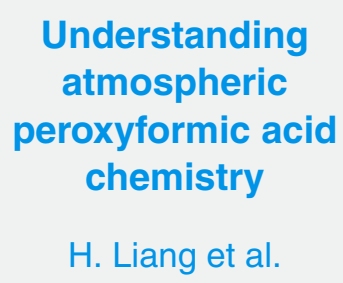

Understanding

atmospheric

peroxyformic acid

chemistry

H. Liang et al.

Title Page

Abstract

Introduction

Conclusions

References

Tables

Figures

14

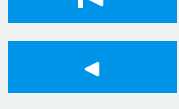

Back

$D$ I

$\triangleright$

Close

Printer-friendly Version

Interactive Discussion 
the PFA/PAA is the $\mathrm{NO}_{\mathrm{x}}$ concentration. It is well known that when $\mathrm{NO}_{\mathrm{x}}$ is high, the peroxyacetyl radical, $\mathrm{CH}_{3} \mathrm{C}(\mathrm{O}) \mathrm{O}_{2}$, will combine with $\mathrm{NO}_{2}$ to yield peroxyacetyl nitrate (PAN) and thus suppress the production of PAA. For PFA, the corresponding peroxyacyl nitrate, i.e. peroxyformyl nitrate has been proved to be very instable and has never 5 been detected in the atmosphere. It is likely that the suppression of $\mathrm{NO}_{2}$ on PFA does not exist. As a result, a higher PFA/PAA tended to be obtained at high $\mathrm{NO}_{\mathrm{x}}$ period.

\subsubsection{PFA vs. MHP}

In general, the concentration of MHP greatly exceeded that of PFA. The daily cycles of PFA and MHP are usually similar as both of them are photochemical products. The

ratio of their concentrations, however, fluctuates greatly from day to day. On some occasions when the solar radiation intensity is relatively stable, PFA tends to be low on the days when MHP is very high, and vice versa. For example, MHP and PFA seemed to be negatively correlated from 30 August to 4 September 2012 during BJ2012S, as is shown in Fig. 4. This can be owing to the fact that the production of

15 MHP and PFA is in competition with each other. Both MHP and PFA are C1 peroxides and are generated from $\mathrm{CH}_{3} \mathrm{O}_{2}$ reactions. The combination of $\mathrm{CH}_{3} \mathrm{O}_{2}$ with $\mathrm{HO}_{2}$ favors producing MHP (R4) while the combination of $\mathrm{CH}_{3} \mathrm{O}_{2}$ with $\mathrm{NO}$ will yield $\mathrm{HCHO}$ (R6 and R7) and the subsequent reactions will result in the production of PFA. However, as is known, reactions between $\mathrm{CH}_{3} \mathrm{O}_{2}$ and $\mathrm{HO}_{2}$ will also produce certain amount of $\mathrm{HCHO}$ (R5). In addition, the photolysis and $\mathrm{OH}$-initiated decomposition of $\mathrm{CH}_{3} \mathrm{OOH}$ will yield $\mathrm{HCHO}$ and hence PFA. Therefore, PFA and MHP have a same source and a competing source simultaneously, leading to the fluctuating ratio of PFA to MHP.

$\mathrm{CH}_{3} \mathrm{O}_{2}+\mathrm{HO}_{2} \rightarrow \mathrm{CH}_{3} \mathrm{OOH}+\mathrm{O}_{2}$

$\mathrm{CH}_{3} \mathrm{O}_{2}+\mathrm{HO}_{2} \rightarrow \mathrm{HCHO}+\mathrm{H}_{2} \mathrm{O}+\mathrm{O}_{2}$

25

$$
\begin{aligned}
& \mathrm{CH}_{3} \mathrm{O}_{2}+\mathrm{NO} \rightarrow \mathrm{CH}_{3} \mathrm{O}+\mathrm{NO}_{2} \\
& \mathrm{CH}_{3} \mathrm{O}+\mathrm{O}_{2} \rightarrow \mathrm{HCHO}+\mathrm{HO}_{2}
\end{aligned}
$$

ACPD

15, 2055-2084, 2015

\section{Understanding \\ atmospheric}

peroxyformic acid

chemistry

$\mathrm{H}$. Liang et al.

Title Page

Abstract

Introduction

Conclusions

References

Tables

Figures

14

$\rightarrow 1$

4

Back

Close

Full Screen / Esc

Printer-friendly Version

Interactive Discussion 


\subsubsection{PFA vs. $\mathrm{H}_{2} \mathrm{O}_{2}$}

The possible conversion from $\mathrm{H}_{2} \mathrm{O}_{2}$ to PFA in the condensed phase has been discussed in Sect. 3.1. There is barely any direct correlation between PFA and $\mathrm{H}_{2} \mathrm{O}_{2}$ in the gas phase. Therefore, in many situations, their temporal profiles differ substan-

5 tially. $\mathrm{H}_{2} \mathrm{O}_{2}$ is often under detection limit when its heterogeneous removal is important whereas PFA seems to be free from heterogeneous removal and can always be detected even on aerosol polluted episodes.

\section{PFA budget}

\subsection{PFA sources}

10 Table 1 presents a summary of the known formation and removal pathways for PFA, and provides the possible range and a best guess of the formation and removal rates in summer urban Beijing.

\subsection{1 $\mathrm{HC}(\mathrm{O}) \mathrm{O}_{2}+\mathrm{HO}_{2}$}

The reaction between peroxy radicals and $\mathrm{HO}_{2}$ is the major known source for various 15 atmospheric peroxides. For PFA, its corresponding precursor, the $\mathrm{HC}(\mathrm{O}) \mathrm{O}_{2}$ radical, generated from the $\mathrm{HC}(\mathrm{O})+\mathrm{O}_{2}$ Reaction (R8), was thought to be instable and can rapidly decompose into $\mathrm{CO}$ and $\mathrm{HO}_{2}$ (Reaction $\mathrm{R} 1$ ). For this reason, Reactions (R8) and (R1) have been simplified as Reaction (R9) in most mechanisms in photochemical models. However, PFA cannot be produced unless stabilized $\mathrm{HC}(\mathrm{O}) \mathrm{O}_{2}$ radicals are formed. Therefore, the importance of this source depends on whether and how much stabilized $\mathrm{HC}(\mathrm{O}) \mathrm{O}_{2}$ radicals can be produced from the $\mathrm{HC}(\mathrm{O})+\mathrm{O}_{2}$ reactions.

$\mathrm{HC}(\mathrm{O})+\mathrm{O}_{2} \rightarrow \mathrm{HC}(\mathrm{O}) \mathrm{O}_{2}$

ACPD

15, 2055-2084, 2015

\section{Understanding}

atmospheric

peroxyformic acid

chemistry

H. Liang et al.

Title Page

Abstract

Introduction

Conclusions

References

Tables

Figures

14

\section{।}

4

Back

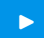

Close

Full Screen / Esc

Printer-friendly Version

Interactive Discussion 
To resolve this issue, efforts were made by a number of previous studies. Yang et al. (2006) proposed that the radical product from the $\mathrm{HC}(\mathrm{O})+\mathrm{O}_{2}$ reaction could have a stable $\mathrm{HC}(\mathrm{O}) \mathrm{O}_{2}$ structure based on the ab initio approach. Villano et al. (2010) observed the isolated $\mathrm{HC}(\mathrm{O}) \mathrm{O}_{2}$ radical in a laboratory study using negative ion photoelectron spectroscopy. The corresponding $\mathrm{HC}(\mathrm{O}) \mathrm{O}_{2}$ radical in their study, however, was produced by electron photodetachment from the peroxyformyl anion rather than directly from the $\mathrm{HC}(\mathrm{O})+\mathrm{O}_{2}$ reaction. Therefore, there is no conclusive evidence whether stabilized $\mathrm{HC}(\mathrm{O}) \mathrm{O}_{2}$ radical can be produced through the $\mathrm{HC}(\mathrm{O})+\mathrm{O}_{2}$ reaction. An only existing recommendation for the yield of the stabilized $\mathrm{HC}(\mathrm{O}) \mathrm{O}_{2}$ radical from the $\mathrm{HC}(\mathrm{O})+\mathrm{O}_{2}$ 10 reaction can be found in Demerjian et al. (1974), in which a yield of $\sim 30 \%$ was suggested to best fit the experimental data.

To calculate the rate of the $\mathrm{HC}(\mathrm{O}) \mathrm{O}_{2}+\mathrm{HO}_{2}$ reaction, we assumed that the concentration of $\mathrm{HC}(\mathrm{O}) \mathrm{O}_{2}$ radical was $1 / 100$ to $1 / 10$ of the $\mathrm{HO}_{2}$ concentration. The average concentration of $\mathrm{HO}_{2}$ radical in summer Beijing, was typically (1-8) $\times 10^{8}$ molecule $\mathrm{cm}^{-3}$ 15 in sunny days, as reported by Liu et al. (2012). Thus we estimated the concentration of $\mathrm{HC}(\mathrm{O}) \mathrm{O}_{2}$ radical as $(1-80) \times 10^{6}$ molecules $\mathrm{cm}^{-3}$. The rate constant of the $\mathrm{HC}(\mathrm{O}) \mathrm{O}_{2}+\mathrm{HO}_{2}$ reaction was assumed to be the same with the $\mathrm{CH}_{3} \mathrm{C}(\mathrm{O}) \mathrm{O}_{2}+\mathrm{HO}_{2}$ reaction. The estimated rate range for the $\mathrm{HC}(\mathrm{O}) \mathrm{O}_{2}+\mathrm{HO}_{2}$ reaction in summer Beijing was listed in Table 1. To verify the exact contribution of this source, the exact concentration 20 of the $\mathrm{HC}(\mathrm{O}) \mathrm{O}_{2}$ radical and the relevant kinetic parameters are required.

\subsection{2 $\mathrm{HC}(\mathrm{O}) \mathrm{O}_{2}+\mathrm{HCHO}$}

This reaction was proposed in early studies of $\mathrm{HCHO}$ photoreactions (e.g., Sodeau and Lee, 1981) and the oxidation of formyl radicals (Osif and Heicklen, 1976). Like the $\mathrm{HC}(\mathrm{O}) \mathrm{O}_{2}+\mathrm{HO}_{2}$ reaction, the importance of $\mathrm{HC}(\mathrm{O}) \mathrm{O}_{2}+\mathrm{HCHO}$ is also dependent on

$$
\mathrm{HC}(\mathrm{O}) \mathrm{O}_{2}+\mathrm{HCHO} \rightarrow \mathrm{HC}(\mathrm{O}) \mathrm{OOH}+\mathrm{HC}(\mathrm{O})
$$

ACPD

15, 2055-2084, 2015

$$
\begin{aligned}
& \text { Understanding } \\
& \text { atmospheric } \\
& \text { peroxyformic acid } \\
& \text { chemistry } \\
& \text { H. Liang et al. }
\end{aligned}
$$

Title Page

Abstract

Introduction

Conclusions

References

Tables

Figures

14

4

Back

Full Screen / Esc

Printer-friendly Version

Interactive Discussion 
The rate constant for this reaction has not been reported yet and was assumed the same with the $\mathrm{HO}_{2}+\mathrm{HCHO}$ reaction.

\subsubsection{Chloroethylenes ozonolysis}

Another known source for PFA is the ozonolysis of chloroethylenes, which was con-

5 firmed in laboratory studies (Niki et al., 1982). This ozonolysis reaction was suggested to produce the $\mathrm{H}(\mathrm{Cl}) \mathrm{COO}$ radical as a Criegee intermediate, which could form PFA via the subsequent reactions. Due to the low concentrations of chloroethylenes in the real atmosphere, the contribution of this reaction to PFA source is limited.

\subsubsection{Aqueous photolysis of methylglyoxal}

10 The aqueous phase photolysis was speculated to be a potentially important source for PFA by analogy with the yield of PAA from biacetyl photolysis (Faust et al., 1997). Because methylglyoxal (MG) has a high solubility (with a Henry's law constant of $3 \times 10^{4} \mathrm{Matm}^{-1}$, Zhou and Mopper, 1990) and is abundant in the gas phase, the typical concentration of $M G$ in the aqueous phase is about $100-300 \mu \mathrm{M}$. The listed range of 15 rate in Table 1 is the result of a clear day case. In a foggy day, the production rate of PFA in this pathway could be 2 or 3 orders of magnitude higher than the clear day value, owing to the greatly enhanced liquid water content compared to clear days. An uncertainty for this source is that MG is readily to form hydrate, which may greatly suppress the photolysis (Faust et al., 1997).

\subsection{5 $\mathrm{HOCH}_{2} \mathrm{OOH}+\mathrm{OH}$}

In addition to the above sources, Francisco and Eisfeld (2009) proposed that the $\mathrm{OH}$ initiated reaction of hydroxymethyl hydroperoxide (HMHP) could lead to the production of PFA with a small yield. Because HMHP was usually not detected or at a very low level in summer Beijing under most conditions, we presumed this reaction was of little 25 importance compared to other sources.

Understanding atmospheric peroxyformic acid chemistry

H. Liang et al.

Title Page

Abstract

Introduction

Conclusions

References

Tables

Figures

14

$\Delta \mathbf{I}$

Back

$>$

Close

Full Screen / Esc

Printer-friendly Version

Interactive Discussion 
According to the range of rates in Table 1, gas phase reactions, in particular $\mathrm{HC}(\mathrm{O}) \mathrm{O}_{2}+\mathrm{HO}_{2}$ and $\mathrm{HC}(\mathrm{O}) \mathrm{O}_{2}+\mathrm{HCHO}$ reactions are likely to be the major sources for PFA in urban Beijing.

\section{ACPD}

$15,2055-2084,2015$

\subsection{PFA sinks}

5 As reported in the literatures (e.g., Lee et al., 2000; Reeves and Penkett, 2003), photolysis, $\mathrm{OH}$-reactions and depositions are three major removal pathways for peroxides. Therefore, we first give an estimation of the rates of these pathways.

\subsubsection{Photolysis}

The rate constants for the photolysis of PFA are estimated by analogy with the corresponding reactions of PAA.

\subsubsection{OH-reaction}

The rate constants for the $\mathrm{OH}$-reaction of PFA are estimated by analogy with the corresponding reactions of PAA.

\subsubsection{Deposition}

15 The deposition rate is the value measured for organic peroxides, which is smaller than or equals to the measured value for $\mathrm{H}_{2} \mathrm{O}_{2}$.

\subsubsection{Decomposition into formic acid}

Besides the above removal pathways, the spontaneous decomposition into formic acid is a significant loss for PFA, even at a low temperature (Giguère and Olmos, 1952).

20 The rate constant for this decomposition, however, has never been investigated to our knowledge. The best guess of the rate in Table 1 is based on the assumption that

Title Page 
PFA has a lifetime of $45 \mathrm{~min}$, according to the fact that PFA was not detected but FA was detected after a $45 \mathrm{~min}$ reaction of $\mathrm{HC}(\mathrm{O})$ oxidation in a laboratory study (Osif and Heicklen, 1976).

\subsection{Heterogeneous reactions}

5 The heterogeneous reaction is of potential importance to the budget of PFA at regions with high aerosol loading, such as urban areas. The kinetics and mechanisms for the heterogeneous production or removal of PFA, however, have not been investigated. The observations have provided some evidence for the importance of the heterogeneous reactions. First, high concentrations of PFA occasionally occurred at night, indicating there is some nighttime PFA source. The known gas phase sources, however, are highly subject to the solar radiation and are not able to contribute to a nighttime production. Therefore, nighttime PFA is likely to originate from heterogeneous reactions. Second, in our previous studies, we have proposed that $\mathrm{H}_{2} \mathrm{O}_{2}$ could convert to PAA rapidly in the aqueous phase under certain conditions (Liang et al., 2013). As PFA and 15 PAA have a similar variation trend in the rainwater, the conversion from $\mathrm{H}_{2} \mathrm{O}_{2}$ to PFA may also exist. $\mathrm{H}_{2} \mathrm{O}_{2}$ is known to have abundant sources in the condensed phase, such as the decomposition of organic complexes, the hydrolysis of hydroxyl hydroperoxides and the transition metal ion catalyzed $\mathrm{HO}_{2}+\mathrm{O}_{2}^{-}$reactions (Arellanes et al., 2006). Some of these sources are independent of solar radiation, providing favorable conditions for the conversion from $\mathrm{H}_{2} \mathrm{O}_{2}$ to PFA at both daytime and nighttime. Considering its low solubility and high volatility, PFA could be quickly released into the gas phase once produced in the condensed phase.

\section{Atmospheric implications of $\mathrm{HC}(\mathrm{O}) \mathrm{O}_{2}$ and PFA chemistry}

In this section, we will employ the box model to examine the impact of PFA and

$\mathrm{HC}(\mathrm{O}) \mathrm{O}_{2}$ radical related chemistry on oxidant budget and formic acid production. PFA

\section{Understanding atmospheric peroxyformic acid chemistry \\ $\mathrm{H}$. Liang et al.}

Title Page 
and $\mathrm{HC}(\mathrm{O}) \mathrm{O}_{2}$ related reactions listed in Table $\mathrm{S} 1$ are included in the box model. As is discussed in Sect. 4.1, the $\mathrm{HC}(\mathrm{O}) \mathrm{O}_{2}$ radical reactions are likely to be the major source for PFA. In addition to the PFA producing reactions, the $\mathrm{HC}(\mathrm{O}) \mathrm{O}_{2}$ radical can proceed other reaction pathways. Peroxy radicals can react with $\mathrm{NO}, \mathrm{NO}_{2}, \mathrm{NO}_{3}$, other organic 5 peroxy radicals and $\mathrm{O}_{3}$, as is reviewed by Orlando and Tyndall (2012) recently. Therefore, we assume that $\mathrm{HC}(\mathrm{O}) \mathrm{O}_{2}$ radical could proceed the same reaction pathways and that the rate constants are the same with the corresponding reactions of $\mathrm{CH}_{3} \mathrm{C}(\mathrm{O}) \mathrm{O}_{2}$ radical. Aqueous phase or heterogeneous reactions are not included in the current studies, due to the lack of sufficient information. Because the $\mathrm{HC}(\mathrm{O}) \mathrm{O}_{2}$ radical produc10 tion yield from $\mathrm{HC}(\mathrm{O})+\mathrm{O}_{2}$ reaction is not sure, we use a series of yield values from 10 to $80 \%$ in different model cases. The model results are shown in Figs. 5 and 6.

According to the current knowledge, FA is formed photochemically from the oxidation of biogenic VOCs (majorly isoprene) and their products (Paulot et al., 2011). In the present study, we take into account two new production pathways for FA, i.e., 5 the reaction of the $\mathrm{HC}(\mathrm{O}) \mathrm{O}_{2}$ radical with $\mathrm{HO}_{2}$ or organic peroxy radicals and the degradation of PFA. Figure 5 compares the FA production from $\mathrm{HC}(\mathrm{O}) \mathrm{O}_{2}$ chemistry (hereafter $\mathrm{HC}(\mathrm{O}) \mathrm{O}_{2}$ pathway) and PFA chemistry (hereafter PFA pathway) and the photo-oxidation of isoprene and its products (hereafter ISO pathway). It is apparent that FA produced from both the $\mathrm{HC}(\mathrm{O}) \mathrm{O}_{2}$ and PFA pathways increase linearly with the $\mathrm{HC}(\mathrm{O}) \mathrm{O}_{2}$ yield increase, whereas FA produced from the ISO pathway is nearly unaffected by the yield change. It can be seen that the $\mathrm{NO}_{\mathrm{x}}$ emission dependences of different pathways are different. Under the high $\mathrm{NO}$ emission rate condition $\left(\geq 6.0 \times 10^{11}\right.$ molecules $\left.\mathrm{cm}^{2} \mathrm{~s}^{-1}\right), \mathrm{HC}(\mathrm{O}) \mathrm{O}_{2}$ and PFA pathways generally make minor contribution to the FA production, compared to the ISO pathways. Under this condition, PFA pathway can be comparable with ISO pathway only when the $\mathrm{HC}(\mathrm{O}) \mathrm{O}_{2}$ yield reaches $80 \%$. When the $\mathrm{NO}$ emission rate is low $\left(\leq 1.2 \times 10^{11}\right.$ molecules $\left.\mathrm{cm}^{2} \mathrm{~s}^{-1}\right)$, however, the $\mathrm{HC}(\mathrm{O}) \mathrm{O}_{2}$ and PFA pathways will dominate over the ISO pathways, even if the $\mathrm{HC}(\mathrm{O}) \mathrm{O}_{2}$ yield is only $10 \%$. This result indicates that the $\mathrm{HC}(\mathrm{O}) \mathrm{O}_{2}$ and PFA pathways are the major FA sources under low $\mathrm{NO}_{\mathrm{x}}$ conditions. In our modeling cases, the maxi-
ACPD

15, 2055-2084, 2015

Understanding

atmospheric

peroxyformic acid

chemistry

H. Liang et al.

Title Page

Abstract

Introduction

Conclusions

References

Tables

Figures

14

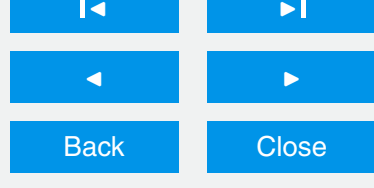

Full Screen / Esc

Printer-friendly Version

Interactive Discussion 
mum FA production rates from $\mathrm{HC}(\mathrm{O}) \mathrm{O}_{2}$ and PFA pathways are calculated to be from 0.004 to $0.03 \mathrm{ppbvh}^{-1}$ at a $\mathrm{HC}(\mathrm{O}) \mathrm{O}_{2}$ yield of from 10 to $80 \%$. Due to the chemical inertness of $\mathrm{FA}$, this production rate will result in the accumulation of FA in the atmosphere. In addition to the gas phase reactions, PFA can also react with aldehydes in the 5 aqueous or aerosol phase to form FA. This part of FA production was not included in the present study, as mentioned above. Because methane and formaldehyde, the precursors of $\mathrm{HC}(\mathrm{O}) \mathrm{O}_{2}$ and $\mathrm{PFA}$, are existing ubiquitously in the global atmosphere, the FA formation from $\mathrm{HC}(\mathrm{O}) \mathrm{O}_{2}$ and PFA pathways is of importance in the understanding of missing secondary sources for FA (Paulot et al., 2011).

10 Figure 6 shows the percentage change of $\mathrm{OH}, \mathrm{HO}_{2}$ and $\mathrm{O}_{3}$ concentrations as well as $\mathrm{HO}_{2}$ production rate after the inclusion of $\mathrm{HC}(\mathrm{O}) \mathrm{O}_{2}$ and PFA chemistry in the box model. Interestingly, we found that the $\mathrm{HC}(\mathrm{O}) \mathrm{O}_{2}$ and PFA chemistry leads to a decrease of $\mathrm{OH}$ and $\mathrm{HO}_{2}$ under low $\mathrm{NO}$ emission conditions $(\leq 1.2 \times$ $10^{11}$ molecules $\mathrm{cm}^{2} \mathrm{~s}^{-1}$ ) but an increase of $\mathrm{OH}$ and $\mathrm{HO}_{2}$ under high $\mathrm{NO}$ emission con15 ditions $\left(\geq 6.0 \times 10^{11}\right.$ molecules $\left.\mathrm{cm}^{2} \mathrm{~s}^{-1}\right)$. Because the $\mathrm{HC}(\mathrm{O})+\mathrm{O}_{2}$ Reaction $(\mathrm{R} 9)$ is one of the major primary sources of $\mathrm{HO}_{2}$, the addition of the $\mathrm{HC}(\mathrm{O}) \mathrm{O}_{2}$ radical production pathway (R8) in the model would suppress the $\mathrm{HO}_{2}$ production. However, the formation of the $\mathrm{HC}(\mathrm{O}) \mathrm{O}_{2}$ radical will not lead to the loss of total $\mathrm{RO}_{\mathrm{x}}\left(\mathrm{OH}, \mathrm{HO}_{2}\right.$ and $\left.\mathrm{RO}_{2}\right)$ radicals, as $\mathrm{HC}(\mathrm{O}) \mathrm{O}_{2}$ radical can recycle back to $\mathrm{HO}_{2}$ and subsequently $\mathrm{OH}$ via its reaction 20 with $\mathrm{NO}$. The loss of $\mathrm{RO}_{\mathrm{x}}$ radical occurs until the $\mathrm{HC}(\mathrm{O}) \mathrm{O}_{2}$ radical combines with $\mathrm{HO}_{2}$ to form PFA and PFA is removed through dry deposition or degradation into FA. Under low $\mathrm{NO}$ emission conditions, the $\mathrm{HC}(\mathrm{O}) \mathrm{O}_{2}$ radical favors combining with $\mathrm{HO}_{2}$ radical to form PFA, thus resulting in the net loss of $\mathrm{RO}_{\mathrm{x}}$ radicals. Under high $\mathrm{NO}$ emission conditions, however, the $\mathrm{HC}(\mathrm{O}) \mathrm{O}_{2}$ radical favors reacting with $\mathrm{NO}$ to yield $\mathrm{HO}_{2}$, thus leading 25 to no net loss of $\mathrm{RO}_{\mathrm{x}}$ radicals but the weakened suppression of $\mathrm{NO}$ on $\mathrm{HO}_{\mathrm{x}}$. Overall, the impact of mechanistic change on $\mathrm{OH}$ and $\mathrm{HO}_{2}$ is not significant when the $\mathrm{HC}(\mathrm{O}) \mathrm{O}_{2}$ yield is less than $20 \%$. If the $\mathrm{HC}(\mathrm{O}) \mathrm{O}_{2}$ yield is $50 \%$ or higher, however, the $\mathrm{HC}(\mathrm{O}) \mathrm{O}_{2}$ and PFA chemistry has to be considered to perform a better simulation for both the concentrations and budgets of $\mathrm{OH}$ and $\mathrm{HO}_{2}$. In addition, the mechanistic change will
ACPD

15, 2055-2084, 2015

Understanding

atmospheric

peroxyformic acid

chemistry

H. Liang et al.

Title Page

Abstract

Introduction

Conclusions

References

Tables

Figures

14

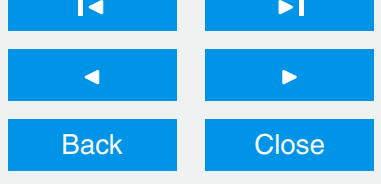

Full Screen / Esc

Printer-friendly Version

Interactive Discussion 
not result in a great change of ozone concentration even if the $\mathrm{HC}(\mathrm{O}) \mathrm{O}_{2}$ yield is up to $80 \%$.

\section{Summary and conclusions}

For the first time, the observation data of peroxyformic acid (PFA) obtained from four 5 field measurements, namely, BJ-2012S, BJ-2012F, BJ-2013 and GC-2013, were presented in the current study. These measurements have made clear that PFA can stay in the atmosphere in a certain amount, typically dozens of pptv. Like other peroxides, PFA was photochemically produced, reaching a peak concentration in the late afternoon. Rainwater measurements demonstrated that PFA can also stay in the atmospheric 10 aqueous phase. The Henry's law constant for PFA, however, is very low, reaching only a quarter of that for PAA. This value suggested that PFA would rapidly release into the gas phase once formed in the aqueous phase. On the basis of an analysis of the correlations between PFA and other peroxides, we found that PFA had a strong positive correlation with PAA, which may be due to their similar sources and sinks. In contrast,

PFA was sometimes inversely correlated with MHP, due to their competitive production.

Based on the comparison of possible reaction rates of each source or sink, we proposed that the peroxyformyl radical $\left(\mathrm{HC}(\mathrm{O}) \mathrm{O}_{2}\right)$ reactions are the major sources and the degradation into formic acid is the major sink for PFA. Box model calculations based on Carbon Bond 6 (CB6) mechanism were performed to evaluate the impact of $\mathrm{HC}(\mathrm{O}) \mathrm{O}_{2}$ and PFA chemistry on FA production and radical budget. The results showed that $\mathrm{HC}(\mathrm{O}) \mathrm{O}_{2}$ and PFA reactions are significant sources for FA under low NO emission conditions, with a maximum production rate of from 0.004 to $0.030 \mathrm{ppbvh}^{-1}$, depending on the yield of $\mathrm{HC}(\mathrm{O}) \mathrm{O}_{2}$ radical from $\mathrm{HC}(\mathrm{O})+\mathrm{O}_{2}$ reaction. The neglect of $\mathrm{HC}(\mathrm{O}) \mathrm{O}_{2}$ and PFA chemistry will cause a model bias of less than $10 \%$ for $\mathrm{OH}$ and $\mathrm{HO}_{2}$ concenHowever, if this yield reaches $50 \%$ or higher, $\mathrm{HC}(\mathrm{O}) \mathrm{O}_{2}$ and PFA chemistry should be considered for radical prediction.

\section{ACPD}

15, 2055-2084, 2015

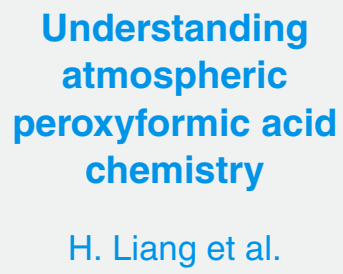

Understanding

atmospheric

peroxyformic acid

chemistry

$\mathrm{H}$. Liang et al.

Title Page

Abstract

Introduction

Conclusions

References

Tables

Figures

14

$\Delta \mathbf{I}$

4

Back

$\triangleright$

Close

Full Screen / Esc

Printer-friendly Version

Interactive Discussion 


\section{The Supplement related to this article is available online at doi:10.5194/acpd-15-2055-2015-supplement.}

Acknowledgements. This work was financed by the National Natural Science Foundation of China (grants 41275125, 21190053, 21477002). The authors acknowledge the Gucheng obser5 vation team for supporting the field peroxide measurement. The authors wish to thank $\mathrm{Y}$. S. Wu and M. Hu (Peking University) for supporting the data of the meteorological factors and common gases used in this publication.

\section{References}

Arellanes, C., Paulson, S. E., Fine, P. M., and Sioutas, C.: Exceeding of Henry's law by hydrogen peroxide associated with urban aerosols, Environ. Sci. Technol., 40, 4859-4866, doi:10.1021/es0513786, 2006.

Demerjian, K. L., Kerr, J. A., and Calvert, J. G.: Advances in Environmental Science and Technology, Wiley, New York, 189 pp., 1974.

Faust, B. C., Powell, K., Rao, C. J., and Anastasio, C.: Aqueous-phase photolysis of biacetyl (an $\alpha$-dicarbonyl compound): a sink for biacetyl, and a source of acetic acid, peroxyacetic acid, hydrogen peroxide, and the highly oxidizing acetylperoxyl radical in aqueous aerosols, fogs, and clouds, Atmos. Environ., 31, 497-510, doi:10.1016/s1352-2310(96)00171-9, 1997.

Francisco, J. S. and Eisfeld, W.: Atmospheric oxidation mechanism of hydroxymethyl hydroperoxide, J. Phys. Chem. A, 113, 7593-7600, doi:10.1021/jp901735z, 2009.

Giguère, P. A. and Olmos, A. W.: A spectroscopic study of hydrogen bonding in performic and peracetic acids, Can. J. Chem., 30, 821-830, doi:10.1139/v52-099, 1952.

Hall, B. D. and Claiborn, C. S.: Measurements of the dry deposition of peroxides to a Canadian boreal forest, J. Geophys. Res., 102, 29343-29353, doi:10.1029/97JD01113, 1997.

He, S. Z., Chen, Z. M., Zhang, X., Zhao, Y., Huang, D. M., Zhao, J. N., Zhu, T., Hu, M., and Zeng, L. M.: Measurement of atmospheric hydrogen peroxide and organic peroxides in Beijing before and during the 2008 Olympic Games: chemical and physical factors influencing their concentrations, J. Geophys. Res., 115, D17307, doi:10.1029/2009jd013544, 2010.
ACPD

15, 2055-2084, 2015

\section{Understanding \\ atmospheric \\ peroxyformic acid \\ chemistry \\ H. Liang et al.}

Title Page

Abstract

Introduction

Conclusions

References

Tables

Figures

14

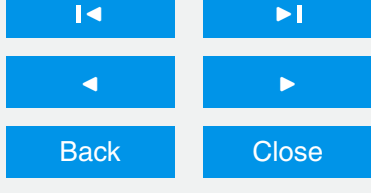

Full Screen / Esc

Printer-friendly Version

Interactive Discussion 
Hilal, S. H., Ayyampalayam, S. N., and Carreira, L. A.: Air-liquid partition coefficient for a diverse set of organic compounds: Henry's law constant in water and hexadecane, Environ. Sci. Technol., 42, 9231-9236, 2008.

Hua, W., Chen, Z. M., Jie, C. Y., Kondo, Y., Hofzumahaus, A., Takegawa, N., Chang, C. C., Lu, K. D., Miyazaki, Y., Kita, K., Wang, H. L., Zhang, Y. H., and Hu, M.: Atmospheric hydrogen peroxide and organic hydroperoxides during PRIDE-PRD'06, China: their concentration, formation mechanism and contribution to secondary aerosols, Atmos. Chem. Phys., 8, 67556773, doi:10.5194/acp-8-6755-2008, 2008.

Huang, D., Chen, Z. M., Zhao, Y., and Liang, H.: Newly observed peroxides and the water effect on the formation and removal of hydroxyalkyl hydroperoxides in the ozonolysis of isoprene, Atmos. Chem. Phys., 13, 5671-5683, doi:10.5194/acp-13-5671-2013, 2013.

Kok, G. L., McLaren, S. E., and Stafflbach, T. A.: HPLC determination of atmospheric organic hydroperoxides, J. Atmos. Ocean. Tech., 12, 282-289, doi:10.1175/15200426(1995)012<0282:HDOAOH>2.0.CO;2, 1995.

Kroll, J. H. and Seinfeld, J. H.: Chemistry of secondary organic aerosol: formation and evolution of low-volatility organics in the atmosphere, Atmos. Environ., 42, 3593-3624, doi:10.1016/j.atmosenv.2008.01.003, 2008.

Langford, A. O. and Moore, C. B.: Reaction and relaxation of vibrationally excited formyl radicals, J. Chem. Phys., 80, 4204-4210, doi:10.1063/1.447251, 1984.

20 Lee, M., Heikes, B. G., and O'Sullivan, D. W.: Hydrogen peroxide and organic hydroperoxide in the troposphere: a review, Atmos. Environ., 34, 3475-3494, doi:10.1016/s13522310(99)00432-x, 2000.

Liang, H., Chen, Z. M., Huang, D., Zhao, Y., and Li, Z. Y.: Impacts of aerosols on the chemistry of atmospheric trace gases: a case study of peroxides and $\mathrm{HO}_{2}$ radicals, Atmos. Chem. Phys., 13, 11259-11276, doi:10.5194/acp-13-11259-2013, 2013.

Liu, Z., Wang, Y., Gu, D., Zhao, C., Huey, L. G., Stickel, R., Liao, J., Shao, M., Zhu, T., Zeng, L., Amoroso, A., Costabile, F., Chang, C.-C., and Liu, S.-C.: Summertime photochemistry during CAREBeijing-2007: $\mathrm{RO}_{\mathrm{x}}$ budgets and $\mathrm{O}_{3}$ formation, Atmos. Chem. Phys., 12, 7737-7752, doi:10.5194/acp-12-7737-2012, 2012.

30 Madronich, S.: The Tropospheric Visible Ultra-violet (TUV) model web page, available at: http: //www.acd.ucar.edu/TUV/ (last access: 21 October 2013), 2002.

Madronich, S. and Calvert, J. G.: Permutation reactions of organic peroxy-radicals in the troposphere, J. Geophys. Res., 95, 5697-5715, 1990.
ACPD

15, 2055-2084, 2015

\section{Understanding \\ atmospheric \\ peroxyformic acid \\ chemistry \\ H. Liang et al.}

Title Page

Abstract

Introduction

Conclusions

References

Tables

Figures

14

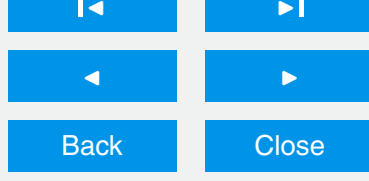

Full Screen / Esc

Printer-friendly Version

Interactive Discussion 
Maker, P. D., Niki, H., Savage, C. M., and Breitenbach, L. P.: Fourier transform infrared spectrometric determination of gaseous performic acid, Anal. Chem., 49, 1346-1347, doi:10.1021/ac50017a016, 1977.

Meylan, W. M. and Howard, P. H.: Src's epi suite, v3.20, Syracuse Research Corporation, Syracuse, NY, 2000.

Niki, H., Maker, P. D., Savage, C. M., Breitenbach, L. P., Martinez, R. I., and Herron, J. T.: A Fourier transform infrared study of the gas-phase reactions of ozone with chloroethylenes. Detection of peroxyformic acid, J. Phys. Chem.-US, 86, 1858-1861, doi:10.1021/j100207a024, 1982.

10 Niki, H., Maker, P. D., Savage, C. M., and Breitenbach, L. P.: FTIR study of the kinetics and mechanism for $\mathrm{Cl}$-atom-initiated reactions of acetaldehyde, J. Phys. Chem.-US, 89, 588591, doi:10.1021/j100250a008, 1985.

Orlando, J. J. and Tyndall, G. S.: Laboratory studies of organic peroxy radical chemistry: an overview with emphasis on recent issues of atmospheric significance, Chem. Soc. Rev., 41, 6294-6317, doi:10.1039/C2cs35166h, 2012.

Osif, T. L. and Heicklen, J.: Oxidation of formyl radicals, J. Phys. Chem.-US, 80, 1526-1531, doi:10.1021/j100555a002, 1976.

Paulot, F., Wunch, D., Crounse, J. D., Toon, G. C., Millet, D. B., DeCarlo, P. F., Vigouroux, C., Deutscher, N. M., González Abad, G., Notholt, J., Warneke, T., Hannigan, J. W., Warneke, C., de Gouw, J. A., Dunlea, E. J., De Mazière, M., Griffith, D. W. T., Bernath, P., Jimenez, J. L., and Wennberg, P. O.: Importance of secondary sources in the atmospheric budgets of formic and acetic acids, Atmos. Chem. Phys., 11, 1989-2013, doi:10.5194/acp-11-19892011, 2011.

Phillips, G. J., Pouvesle, N., Thieser, J., Schuster, G., Axinte, R., Fischer, H., Williams, J., Lelieveld, J., and Crowley, J. N.: Peroxyacetyl nitrate (PAN) and peroxyacetic acid (PAA) measurements by iodide chemical ionisation mass spectrometry: first analysis of results in the boreal forest and implications for the measurement of PAN fluxes, Atmos. Chem. Phys., 13, 1129-1139, doi:10.5194/acp-13-1129-2013, 2013.

Raventos-Duran, T., Camredon, M., Valorso, R., Mouchel-Vallon, C., and Aumont, B.: Structureactivity relationships to estimate the effective Henry's law constants of organics of atmospheric interest, Atmos. Chem. Phys., 10, 7643-7654, doi:10.5194/acp-10-7643-2010, 2010.
ACPD

15, 2055-2084, 2015

Understanding

atmospheric

peroxyformic acid

chemistry

$\mathrm{H}$. Liang et al.

Title Page

Abstract

Introduction

Conclusions

References

Tables

Figures

14

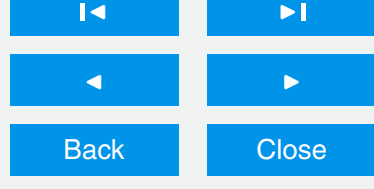

Full Screen / Esc

Printer-friendly Version

Interactive Discussion 
Reeves, C. E. and Penkett, S. A.: Measurements of peroxides and what they tell us, Chem. Rev., 103, 5199-5218, doi:10.1021/cr0205053, 2003.

Sander, S. P., Abbatt, J., Barker, J. R., Burkholder, J. B., Friedl, R. R., Golden, D. M., Huie, R. E., Kolb, C. E., Kurylo, M. J., Moortgat, G. K., Orkin, V. L., and Wine, P. H.: Chemical Kinetics and $5 \quad$ Photochemical Data for Use in Atmospheric Studies, Evaluation No. 17, JPL Publication 106, Jet Propulsion Laboratory, Pasadena, CA, USA, available at: http://jpldataeval.jpl.nasa.gov (last access: June 2012), 2011.

Sodeau, J. S. and Lee, E. K.: Photoreactions of formaldehyde, Rev. Chem. Intermed., 4, 259296, doi:10.1007/BF03052417, 1981.

10 Stein, A. F. and Saylor, R. D.: Sensitivities of sulfate aerosol formation and oxidation pathways on the chemical mechanism employed in simulations, Atmos. Chem. Phys., 12, 8567-8574, doi:10.5194/acp-12-8567-2012, 2012.

Villano, S. M., Eyet, N., Wren, S. W., Ellison, G. B., Bierbaum, V. M., and Lineberger, W. C.: Photoelectron spectroscopy and thermochemistry of the peroxyformate anion, J. Phys. Chem. A, 114, 191-200, doi:10.1021/jp907569w, 2010.

Yang, H. C., Chen, H. L., and Ho, J. J.: Ab initio study of intramolecular hydrogen transfer in formylperoxy radical, J. Mol. Struct., 774, 35-41, doi:10.1016/j.theochem.2006.07.003, 2006.

Yarwood, G., Jung, J., Whitten, G. Z., Heo, G., Mellberg, J., and Estes, M.: Updates to the Carbon Bond mechanism for version 6 (CB6), in: 2010 CMAS Conference, Chapel Hill, NC, 11-13 October, avalaible at: http://www.cmascenter.org/conference/2010/abstracts/emery updates_carbon_2010.pdf (last access: 22 October 2013), 2010.

Yuan, B., Shao, M., de Gouw, J., Parrish, D. D., Lu, S., Wang, M., Zeng, L., Zhang, Q., Song, Y., Zhang, J., and Hu, M.: Volatile organic compounds (VOCs) in urban air: how chemistry affects the interpretation of positive matrix factorization (PMF) analysis, J. Geophys. Res., 117, D24302, doi:10.1029/2012jd018236, 2012.

Zhang, J., Hatakeyama, S., and Akimoto, H.: Rate constants of the reaction of ozone with trans-1,2-dichloroethene and vinyl-chloride in air, Int. J. Chem. Kinet., 15, 655-668, doi:10.1002/kin.550150707, 1983.

so Zhang, X., Chen, Z. M., He, S. Z., Hua, W., Zhao, Y., and Li, J. L.: Peroxyacetic acid in urban and rural atmosphere: concentration, feedback on $\mathrm{PAN}-\mathrm{NO}_{\mathrm{x}}$ cycle and implication on radical chemistry, Atmos. Chem. Phys., 10, 737-748, doi:10.5194/acp-10-737-2010, 2010.

\section{ACPD}

15, 2055-2084, 2015

\section{Understanding \\ atmospheric \\ peroxyformic acid \\ chemistry \\ H. Liang et al.}

Title Page

Abstract

Introduction

Conclusions

References

Tables

Figures

14

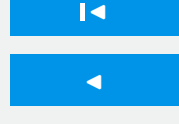

Back

DI

$>$

Close

Printer-friendly Version

Interactive Discussion 
Zhang, X., He, S. Z., Chen, Z. M., Zhao, Y., and Hua, W.: Methyl hydroperoxide $\left(\mathrm{CH}_{3} \mathrm{OOH}\right)$ in urban, suburban and rural atmosphere: ambient concentration, budget, and contribution to the atmospheric oxidizing capacity, Atmos. Chem. Phys., 12, 8951-8962, doi:10.5194/acp12-8951-2012, 2012.

5 Zhou, X. and Mopper, K.: Apparent partition coefficients of 15 carbonyl compounds between air and seawater and between air and freshwater; implications for air-sea exchange, Environ. Sci. Technol., 24, 1864-1869, 1990.

Ziemann, P. J. and Atkinson, R.: Kinetics, products, and mechanisms of secondary organic aerosol formation, Chem. Soc. Rev., 41, 6582-6605, doi:10.1039/C2CS35122F, 2012.

\section{ACPD}

15, 2055-2084, 2015

\section{Understanding atmospheric \\ peroxyformic acid \\ chemistry}

H. Liang et al.

\section{Title Page}

Full Screen / Esc

Printer-friendly Version

Interactive Discussion 


\section{ACPD}

15, 2055-2084, 2015

\section{Understanding atmospheric peroxyformic acid chemistry}

Table 1. An estimation of the rates of atmospheric PFA sources and sinks in Beijing.

\begin{tabular}{|c|c|c|c|c|c|}
\hline $\begin{array}{l}\text { Source } \\
\text { or sink }\end{array}$ & No. & Reactions & Reference & $\begin{array}{l}\text { Range of rates } \\
\left(\mathrm{ppbvh}^{-1}\right)\end{array}$ & $\begin{array}{l}\text { Best guess of rates } \\
\left(p_{\left.p b v h^{-1}\right)}\right.\end{array}$ \\
\hline source & $\mathrm{P} 1$ & $\mathrm{HC}(\mathrm{O}) \mathrm{OO}+\mathrm{HO}_{2} \rightarrow 0.4 \mathrm{HC}(\mathrm{O}) \mathrm{OOH}$ & Sander et al. (2011) & $8.2 \times 10^{-5}-5.2 \times 10^{-1}$ & $6.6 \times 10^{-3}$ \\
\hline source & $\mathrm{P} 2$ & $\mathrm{HC}(\mathrm{O}) \mathrm{OO}+\mathrm{HCHO} \rightarrow \mathrm{HC}(\mathrm{O}) \mathrm{OOH}$ & Osif and Heicklen (1976) & $1.8 \times 10^{-5}-1.4$ & $1.8 \times 10^{-2}$ \\
\hline source & P3 & chloroethylenes ozonolysis & Zhang et al. (1983) & $1.8 \times 10^{-5}-3.5 \times 10^{-3}$ & $2.2 \times 10^{-4}$ \\
\hline source & $\mathrm{P} 4$ & aqueous methyl glyoxal photolysis & Faust et al. (1997) & $4.9 \times 10^{-7}-2.4 \times 10^{-4}$ & $7.6 \times 10^{-6}$ \\
\hline source & P5 & $\mathrm{HOCH}_{2} \mathrm{OOH}+\mathrm{OH} \rightarrow \mathrm{HC}(\mathrm{O}) \mathrm{OOH}$ & Francisco and Eisfeld (2009) & - & - \\
\hline sink & L3 & dry deposition & Hall and Claiborn (1997) & $9.0 \times 10^{-5}-2.9 \times 10^{-2}$ & $7.2 \times 10^{-4}$ \\
\hline sink & $\mathrm{L} 4$ & $2 \mathrm{HC}(\mathrm{O}) \mathrm{OOH} \rightarrow 2 \mathrm{HC}(\mathrm{O}) \mathrm{OH}+\mathrm{O}_{2}$ & - & - & $2.7 \times 10^{-2}$ \\
\hline unknown & U1 & heterogeneous reactions & - & - & - \\
\hline
\end{tabular}

$P$ represents the production pathways; $L$ represents the loss pathways; $U$ represents that the pathway is uncertain to be a source or sink.

\section{H. Liang et al.}

\section{Title Page}

\section{Full Screen / Esc}

Printer-friendly Version

Interactive Discussion 


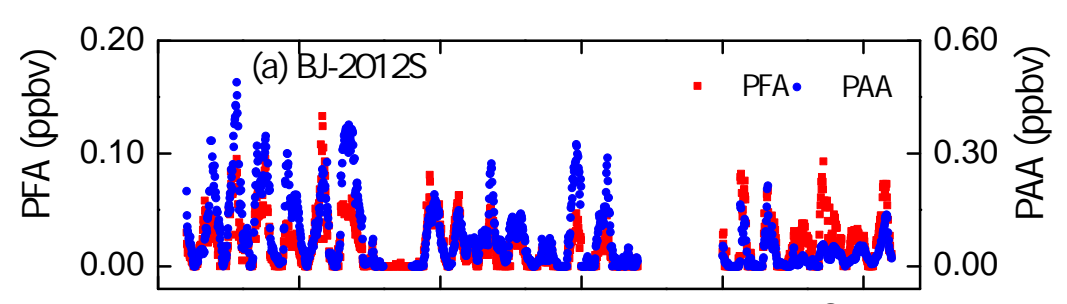

\section{ACPD}

15, 2055-2084, 2015

Understanding atmospheric

peroxyformic acid chemistry

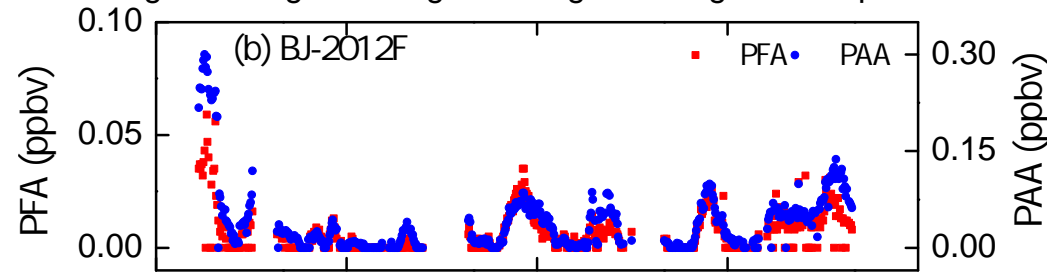

H. Liang et al.

Title Page

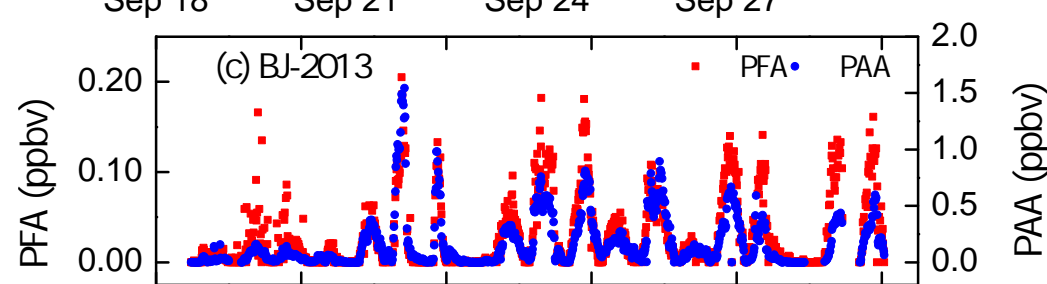

Abstract

Introduction

Conclusions

References

Tables

Figures

14

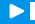

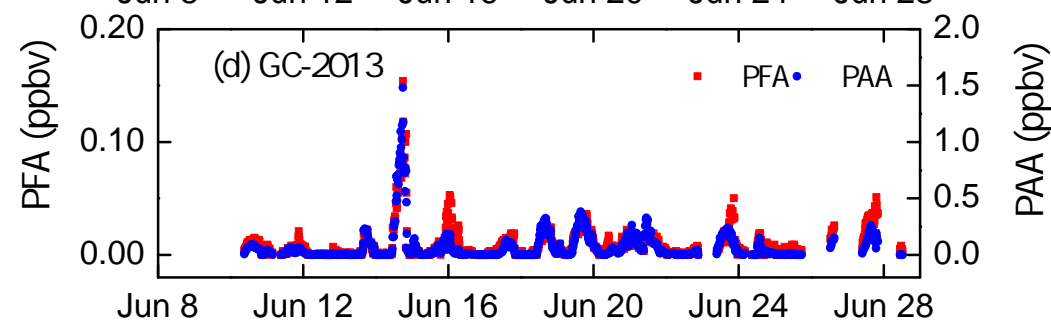

Back

Close

Full Screen / Esc

Printer-friendly Version

Interactive Discussion

Figure 1. Temporal profiles of PFA and PAA during four field measurements. 


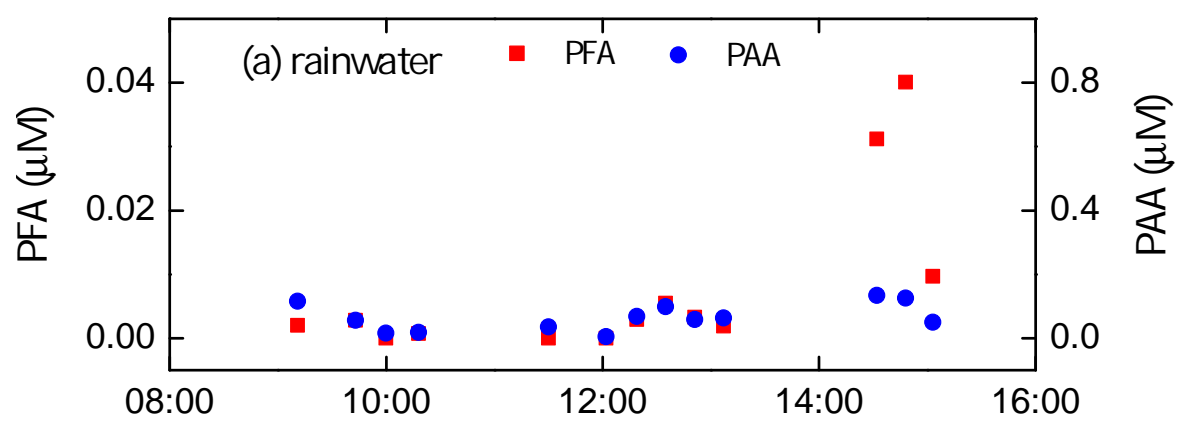

\section{ACPD}

15, 2055-2084, 2015

\section{Understanding atmospheric}

peroxyformic acid chemistry

\section{H. Liang et al.}

Title Page

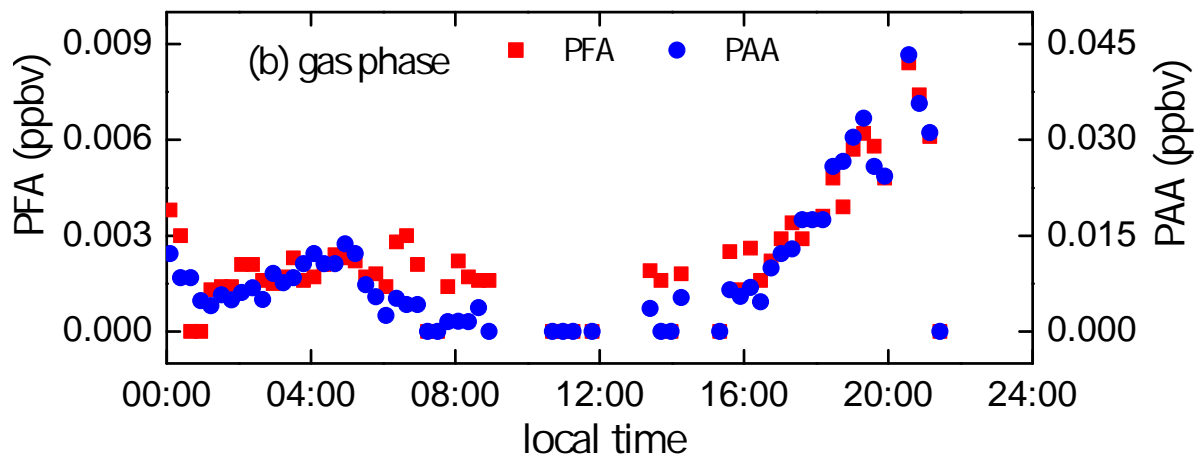

Abstract

Introduction

Conclusions

References

Tables

Figures

14

DI

4

Back

Close

Full Screen / Esc

Printer-friendly Version

Interactive Discussion 

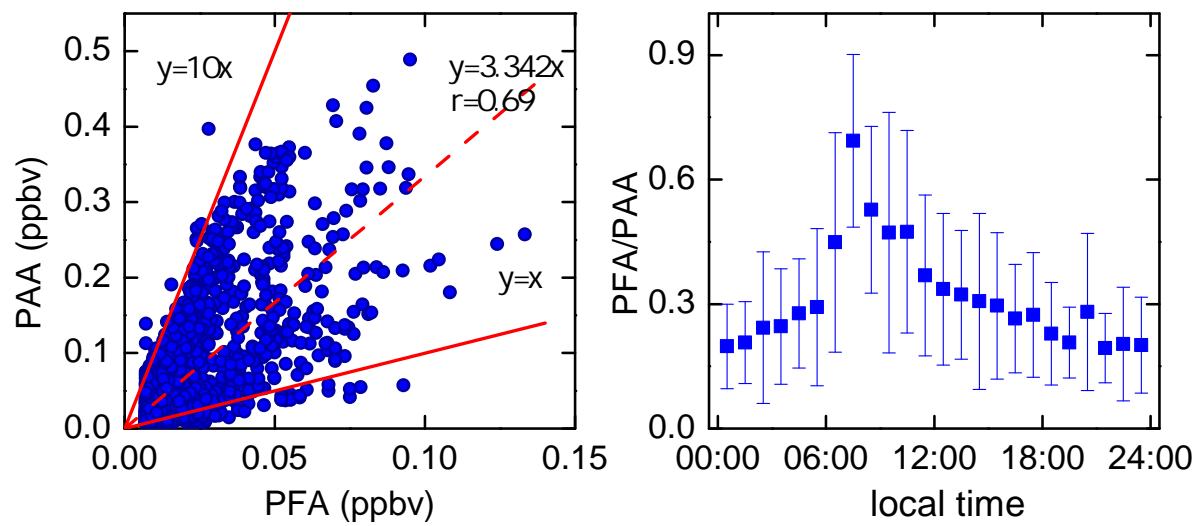

Figure 3. Relationship between PFA and PAA and the hourly average ratio of PFA to PAA for all data during BJ-2012S.

\section{Understanding atmospheric peroxyformic acid chemistry}

\section{H. Liang et al.}

\section{Title Page}

\section{Full Screen / Esc}

Printer-friendly Version

Interactive Discussion 


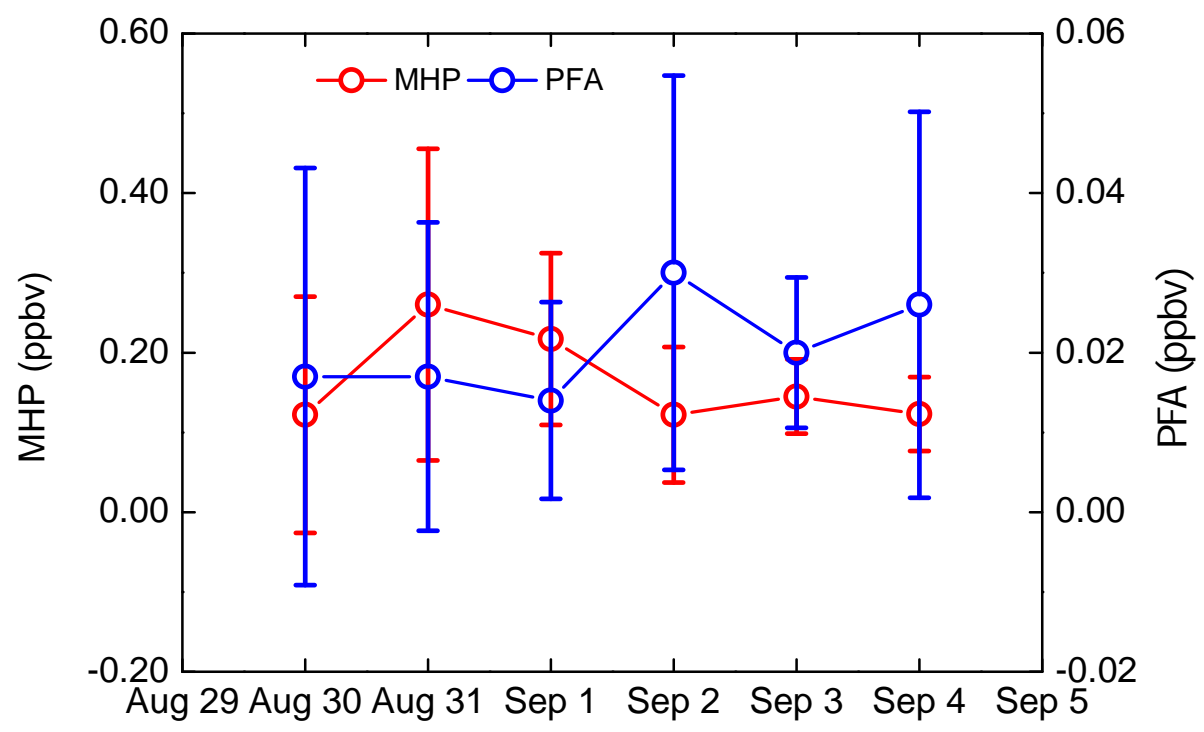

Figure 4. Daily average MHP and PFA from 30 August to 4 September 2012 during BJ-2012S.

\section{ACPD}

15, 2055-2084, 2015

\section{Understanding atmospheric peroxyformic acid chemistry}

\section{H. Liang et al.}

Title Page

14 $>1$

4

Back

Close

Printer-friendly Version

Interactive Discussion 

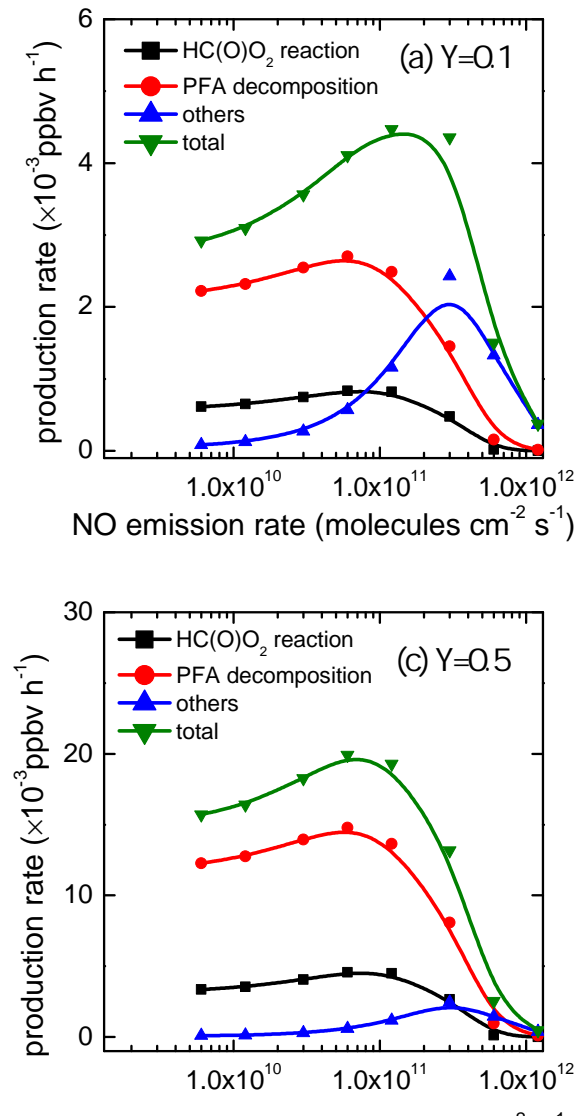

$\mathrm{NO}$ emission rate (molecules $\mathrm{cm}^{-2} \mathrm{~s}^{-1}$ )

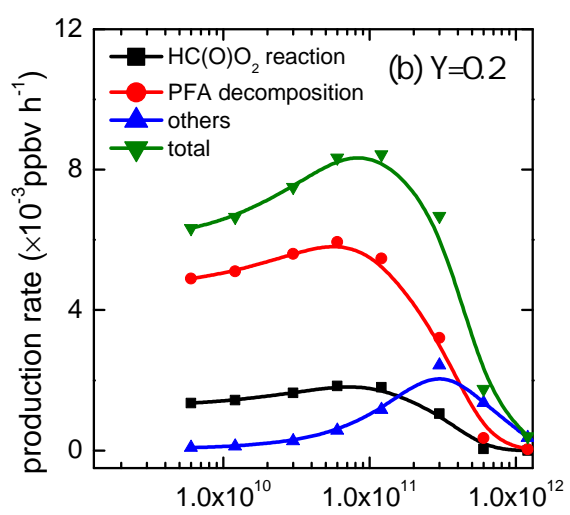

$\mathrm{NO}$ emission rate (molecules $\mathrm{cm}^{-2} \mathrm{~s}^{-1}$ )

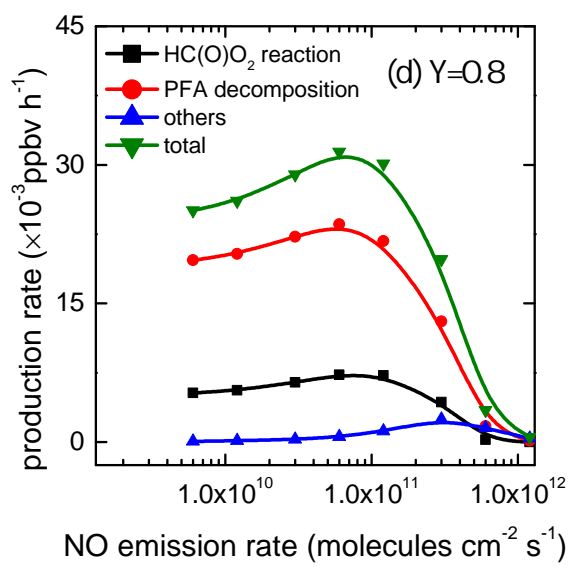

Figure 5. The production rates of formic acid (FA) from different pathways at different $\mathrm{NO}$ emission rate. Black line: FA production rates from $\mathrm{HC}(\mathrm{O}) \mathrm{O}_{2}$ reaction; red line: FA production rates from PFA decomposition; blue line: FA production rates from other pathways; green line: the sum of the above three pathways. $Y$ : the yield of $\mathrm{HC}(\mathrm{O}) \mathrm{O}_{2}$ from $\mathrm{HC}(\mathrm{O})+\mathrm{O}_{2}$ reactions.

\section{ACPD}

15, 2055-2084, 2015

\section{Understanding atmospheric peroxyformic acid chemistry}

\section{H. Liang et al.}

Title Page

\section{Full Screen / Esc}

Printer-friendly Version

Interactive Discussion 


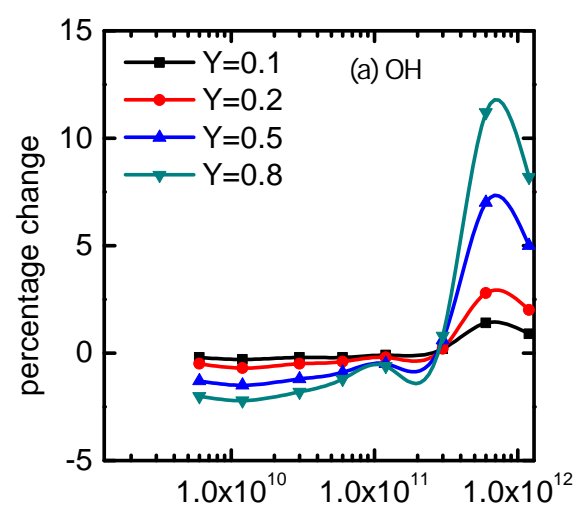

$\mathrm{NO}$ emission rate (molecules $\mathrm{cm}^{-2} \mathrm{~s}^{-1}$ )

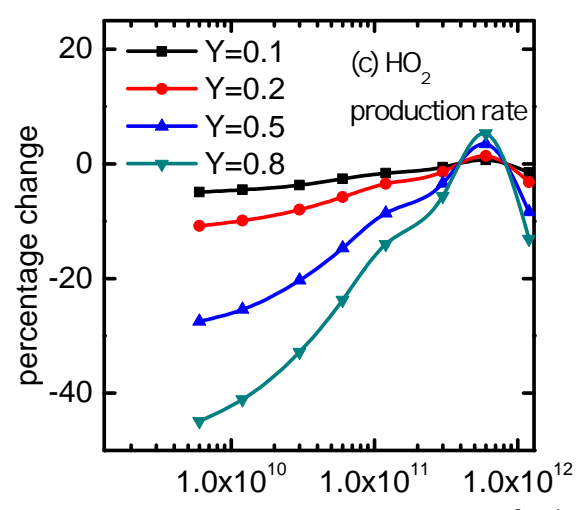

$\mathrm{NO}$ emission rate (molecules $\mathrm{cm}^{-2} \mathrm{~s}^{-1}$ )

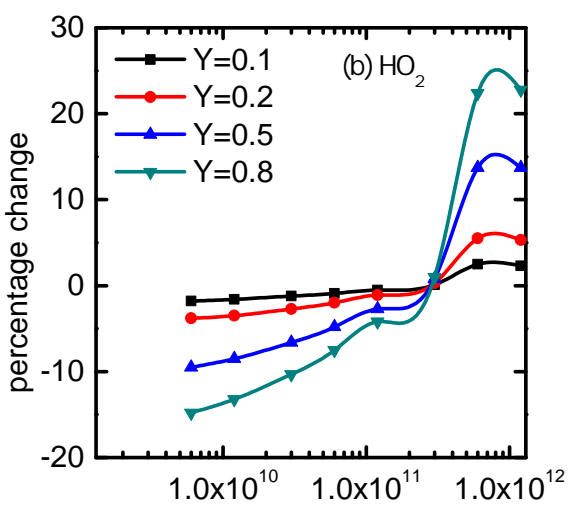

$\mathrm{NO}$ emission rate (molecules $\mathrm{cm}^{-2} \mathrm{~s}^{-1}$ )

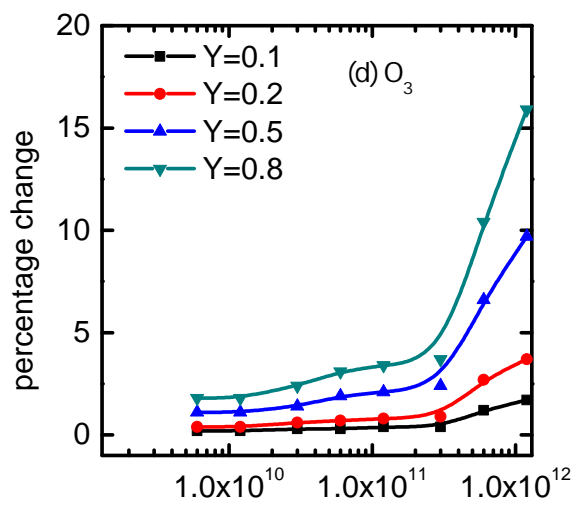

$\mathrm{NO}$ emission rate (molecules $\mathrm{cm}^{-2} \mathrm{~s}^{-1}$ )

\section{ACPD}

15, 2055-2084, 2015

\section{Understanding atmospheric \\ peroxyformic acid chemistry}

\section{H. Liang et al.}

\section{Title Page}

Abstract

Introduction

Conclusions

References

Tables

Figures

14

>

Back

Close

\section{Full Screen / Esc}

Printer-friendly Version

Interactive Discussion to the mechanistic change at different $\mathrm{NO}$ emission rates and different yield of $\mathrm{HC}(\mathrm{O}) \mathrm{O}_{2}$ from $\mathrm{HC}(\mathrm{O})+\mathrm{O}_{2}$ reactions. $Y$ : the yield of $\mathrm{HC}(\mathrm{O}) \mathrm{O}_{2}$ from $\mathrm{HC}(\mathrm{O})+\mathrm{O}_{2}$ reactions. 